\title{
Awareness of Health Care Workers about Infection Control Practice and Occupational Safety at a Tertiary Care Hospital, Cairo, Egypt
}

\author{
Hasnaa A. Abouseif, Sally Adel Hakim and Khaled M. Abd Elaziz
}

Department of Community, Environmental and Occupational medicine, Faculty of medicine, Ain Shams University.

Received: May, $2018 \quad$ Accepted: July, 2018

\begin{abstract}
Background: Biological occupational hazards in the form of needle stick injuries can occur anywhere within the health care organization. Worldwide, the number of health care workers annually exposed to sharp injuries contaminated with HBV, HCV or HIV is estimated at 2.1 million, 926,000 and 327,000 respectively. Objective: To measure the knowledge and attitude of a group of health care workers regarding methods for prevention of needle stick injuries and to identify their response in case of needle stick injury. Methods: A crosssectional study included 98 physicians and 224 nurses. They filled a questionnaire including past history of occupational inquiries, knowledge on some aspects of infection control, their attitude towards occupational safety activities at their workplace and their knowledge of the actions they should do in case of needle stick injury. Results: Most of the participants were females and nurses, (42\%) had history of needle stick injury. Unfortunately, most of participants had insufficient knowledge about some aspects of infection control and negative attitude towards hospital activities for occupational safety. Moreover, their knowledge on actions to be done in case of needle stick injury was inadequate. Pre-employment training, work duration and working in non-surgical departments had an impact on their knowledge.

Conclusion: More programs have to be directed towards raising knowledge on occupational safety and their right to know about both types of hazards and actions to be done in case of exposure is of great importance
\end{abstract}

Keywords: needle stick injuries, actions in case of needle injury, occupational safety at hospitals, Cairo, Egypt.

Corresponding author: Hasnaa A. Abouseif . Email: drhasnaaabouseif@yahoo.com

\section{Introduction}

Needle stick injuries are a common category of occupational hazards which are encountered by health care workers ${ }^{1}$ and have been defined as a skin penetrating wound by a needle point or any other sharp tool contaminated with blood or body fluids. ${ }^{2}$ As a result of their job nature, health care workers are frequently endangered of exposure to needle stick injuries. ${ }^{3}$ The World Health Organization has estimated that in developing regions, $40 \%-65 \%$ of HBV and HCV infections in health care workers are attributable to percutaneous occupational exposure. ${ }^{4}$ The incidence of needle sticks among health care workers varies in different countries. Its prevalence has been reported to be about $66 \%$ in Egypt, $79.5 \%$ in India and $31.4 \%$ in Germany. ${ }^{5,6,7}$ An Egyptian study, using Kane's model to predict infections 
after needle stick occupational exposures, estimated 24,004 hepatitis C virus and 8617 hepatitis B virus infections occurring each year in Egypt as a result of occupational exposure in the health care organization. $^{8}$ The cost of injuries caused by contaminated sharps is estimated to be in the range from 118-591 million dollars in the US 2007. ${ }^{9}$ The problem with these injuries is also its psychological effects as phobia, anxiety and stress in injured staff. $^{10}$

While exposure to blood borne pathogens is one of the most serious hazards that health care workers face on a daily basis, it is also one of the most preventable. Safe injection practices include hand hygiene, use of gloves where appropriate, skin preparation and disinfection and proper waste management. It is therefore, mandatorily advised that safe injection practices should be routinely applied in all health care settings to assure safety. ${ }^{11}$

Actions of health care workers after a needle stick injury are of great importance in alleviating the consequences. Health care workers should take effective actions after such injuries and employers are responsible for implementing protocols to reduce such injuries. ${ }^{12}$ In one study, $77.8 \%$ of subjects sought consultation from physician within an hour of needle stick injury exposure. $91 \%$ of those subjects were suggested to take post exposure prophylaxis (PEP) and among them $88.2 \%$ started PEP. ${ }^{13}$ In UK, $38.5 \%$ of surgeons knew that PEP has to be obtained within 1 hour of the injury, and only $7 \%$ knew from where to obtain PEP. ${ }^{14}$

In a study done by Mathewos et al, 2013 in North West Ethiopia, it was found that the percentage of exposed respondents who took PEP was $(74.2 \%){ }^{15}$

According to OSHA's Blood borne Pathogens Standard, employers should establish an exposure control plan and update it annually, implement the use of universal precautions, identify and use engineering controls, provide personal protective equipment as gloves, aprons, eye protection and masks, also it is important to make available hepatitis B vaccination to all workers at risk and also to make available post exposure evaluation and follow up. ${ }^{16}$

Objective: To measure the knowledge and attitude of a group of health care workers regarding some aspects of infection control practice in health care setting, correct actions taken in case of needle stick injuries and attitude of health care workers towards hospital activities taken for occupational safety.

\section{Methods}

In current cross-sectional study 370 health care workers were asked to fill the questionnaire, of them 48 refused to complete the questionnaire due to either lake of time or interest with response rate $87 \%$. The study included 322 health care workers from Ain Shams University hospitals, Cairo, Egypt in 2016, where 98 were physicians and 224 were nurses. The departments included were internal medicine, obstetrics and gynecology, pediatrics, general surgery, operating theatres and intensive care units.

The sample size was calculated using EpiInfo version 6.1, power of $80 \%$, confidence interval $95 \%$, based on that $38.5 \%$ of surgeons knew that PEP has to be obtained within 1 hour of the injury (14), the worst acceptable level as $33.5 \%$, the sample would be 276 subjects.

The participants filled a questionnaire including data on socio-demographic and occupational characteristics as well as questions on their knowledge about some infection control instructions, attitude of health care workers towards hospital activities for occupational safety and their knowledge of the actions which should be done in case he/she got injured by a needle 
during work. The questions were derived and modified from Redal et al., 2010 study.

Questions related to general knowledge about infection control were 17 with a total score of 17 , questions related to attitude were 6 with a total score of 6 while questions related to knowledge about correct actions to be done in case of needle stick injury were 12 with a total score of 12. Each correct answer or positive attitude was coded (1), each incorrect answer or negative attitude was coded (0). Participants obtaining a score of $70 \%$ or more were considered with adequate knowledge or good attitude (18).

Pilot study: to verify appropriateness of the questionnaire to achieve study objectives, pilot study was conducted including 10 questionnaires. According to results of the pilot study, minimal modifications were done. Results of pilot study were not included in the results of the study.

Data management: Data was coded and entered on SPSS program version 16. Frequency tables and chi square test were used.

\section{Ethical considerations:}

The participants were informed of the study objectives and an informed oral consent was obtained from them to participate in the study. Confidentiality was assured through having anonymous questionnaires.

\section{Results}

The study included 322 participants, 54\% were females. Most of the study group were married, nurses, from the internal medicine department and did not receive pre-employment training on safe use and disposal of needles. $41.9 \%$ had previous history of needle stick injuries and 18\% had history of eye splashes. Mean age \pm SD was $38.2 \pm 7.7$ years and mean work duration was $9.8 \pm 5.4$ years (table 1 ). On describing the knowledge of the study
Table (1): $\quad$ Socio-demographic characteristics of the study population:

\begin{tabular}{|l|c|}
\hline Variables & $\mathbf{N}(\%)$ \\
\hline Mender & $147(45.7)$ \\
Females & $175(54.3)$ \\
\hline Marital status & $217(67.4)$ \\
Married & $105(32.6)$ \\
Unmarried & \\
\hline Job nature & $98(30.4)$ \\
Physicians & $224(69.6)$ \\
nurses & \\
\hline Departments & $142(44.1)$ \\
Internal medicine & $51(15.8)$ \\
Operative theatres & $48(14.9)$ \\
Obstetrics and gynecology & $42(13)$ \\
Pediatrics & $25(7.8)$ \\
General surgery & $14(4.3)$ \\
Intensive care unit & $123(38.2)$ \\
\hline Pre-employment training on & \\
safe use and disposal of & \\
needles & $135(41.9)$ \\
\hline History of needle stick & \\
injuries & $38.2 \pm 7.78$ \\
\hline Age (mean \pm SD) & $9.8 \pm 5.46$ \\
\hline Work duration (mean \pm SD)
\end{tabular}

population about some aspects of infection control, it was found that $75 \%$ had inadequate knowledge (mean \pm SD: $8.93 \pm$ 1.28). The aspects in which knowledge was best recorded were knowing that syringes should not be used after changing needles, the sharps container should be away from public access and covering cuts can protect from infection transmission (table 2). As for actions to be done in case of needle stick injury, most of them knew that a sterile material should be used for drying the wound, report the injury to the supervisor should be done and taking post exposure prophylaxis if the source case was unknown or positive. However, generally most of them had insufficient knowledge on actions in case of needle stick injury and the mean score was $4.77 \pm$ 1.82 (table 3). Most of participants had generally a negative attitude towards 
Table (2): Knowledge of some aspects of infection control:

\begin{tabular}{|c|c|}
\hline Do you know that? & $\begin{array}{l}\text { I know } \\
\text { N }(\%)\end{array}$ \\
\hline $\begin{array}{l}\text { Universal precautions are intended for } \\
\text { infection control }\end{array}$ & $198(61.5)$ \\
\hline $\begin{array}{l}\text { You must wash your hands before } \\
\text { contact with each patient }\end{array}$ & $154(47.8)$ \\
\hline $\begin{array}{l}\text { You must wash your hands after contact } \\
\text { with each patient }\end{array}$ & $218(67.7)$ \\
\hline $\begin{array}{l}\text { Washing hands is an infection control } \\
\text { method }\end{array}$ & $190(59)$ \\
\hline $\begin{array}{l}\text { Washing hands before wearing gloves } \\
\text { is important }\end{array}$ & $137(42.5)$ \\
\hline $\begin{array}{l}\text { You must wash hands after removing } \\
\text { gloves }\end{array}$ & $146(45.3)$ \\
\hline Gloves should be used once & $199(61.8)$ \\
\hline $\begin{array}{l}\text { Gloves should be changed between } \\
\text { patients }\end{array}$ & $162(50.3)$ \\
\hline $\begin{array}{l}\text { Syringes should not be used after } \\
\text { changing needle }\end{array}$ & $248(77)$ \\
\hline No needle recapping or removal & $188(58.4)$ \\
\hline $\begin{array}{l}\text { Sharps should not be passed directly } \\
\text { from hand to hand and handling should } \\
\text { be kept to a minimum }\end{array}$ & $125(38.8)$ \\
\hline $\begin{array}{l}\text { Used needles must not be bent or } \\
\text { broken before disposal }\end{array}$ & $104(32.3)$ \\
\hline $\begin{array}{l}\text { The level at which the safety box should } \\
\text { be emptied after reaching } 2 / 3 \text { its level }\end{array}$ & $206(64)$ \\
\hline $\begin{array}{l}\text { The sharps container must be located in } \\
\text { a safe position that avoids spillage }\end{array}$ & $210(65.2)$ \\
\hline $\begin{array}{l}\text { The sharps container should be away } \\
\text { from public access points and is out of } \\
\text { reach of children }\end{array}$ & $221(68.6)$ \\
\hline $\begin{array}{l}\text { Covering cuts and abrasions can } \\
\text { protect from infection transmission }\end{array}$ & $218(67.7)$ \\
\hline $\begin{array}{l}\text { Open footwear should not be worn in } \\
\text { situations where blood may split }\end{array}$ & $202(62.7)$ \\
\hline \multicolumn{2}{|l|}{ Interpretation of knowledge score } \\
\hline $\begin{array}{l}\text { Inadequate knowledge } \\
\text { Adequate knowledge }\end{array}$ & $\begin{array}{r}278(86.3) \\
44(13.7) \\
\end{array}$ \\
\hline
\end{tabular}

hospital activities for occupational safety. However, points where the highest percentage of participants had a positive attitude were: efforts of quality control teams for follow up of rules implementation and hospital supply of personal protective equipment (table 4). On studying factors that could affect health care workers' knowledge about actions have to be taken in case of needle stick injury, it was found that attending training courses, working years $(<9$ years) and working in non-surgical departments had good knowledge score (table 5).

\section{Discussion}

Needle stick injuries and exposure to splashes of blood and body fluids (BBF) among health care workers have been reported from different parts of the world. A study conducted in an Australian tertiary hospital revealed a rate of $(47 \%)$ for sharp objects related injuries and (68\%) for body fluid exposures among nurses and also reported rates of (38\%) and (16\%) respectively among other medical staff. ${ }^{19}$ Zafar et al., 2008 identified that about $45 \%$ of personnel reported having had a needle stick injury in the past. ${ }^{20}$ The current study showed that about $42 \%$ of the study population experienced previous injuries. Universal precautions are an administrative control measure that calls for protection of health care workers by implementing good practices and maintaining equipment to protect health care workers from potential blood borne infections. ${ }^{21,22}$ In our work about $13 \%$ knew about universal precautions. In one study, which investigated the knowledge and practices towards universal precautions among health care workers in two hospitals in Iran, $65.8 \%$ and $90 \%$ of staff in the two hospitals had heard about universal precautions. ${ }^{23}$ In this study also health care workers showed good understanding concerning disposal of sharps, use of mask and gown. One study found that $90 \%$ of participants knew hand washing was essential after contact with the patient, $83 \%$ knew they should wear gloves. ${ }^{24}$ In the current study, 55\% reported knowing that hand wash is an infection control method, $64 \%$ washed their hands after contact with each patient, $44 \%$ before contact, $37 \%$ before wearing gloves and $39 \%$ after removing gloves. 56\% knew that gloves should be used once and $46 \%$ said they should change gloves between patients. These findings could be compared with the findings in another 
Table (3): Knowledge of correct actions in case of needle stick injuries:

\begin{tabular}{|l|c|}
\hline $\begin{array}{l}\text { In case of needle stick injury, do } \\
\text { you know you should? }\end{array}$ & No. (\%) \\
\hline $\begin{array}{l}\text { Use a sterile material to dry the } \\
\text { wound }\end{array}$ & $208(64.6)$ \\
\hline Report the injury to the supervisor & $183(56.8)$ \\
\hline Test yourselffor HIV/HCV/HBV & $183(56.8)$ \\
\hline $\begin{array}{l}\text { Search for the health status of the } \\
\text { source case }\end{array}$ & $169(52.5)$ \\
\hline $\begin{array}{l}\text { Wash the site of injury with soap } \\
\text { and water }\end{array}$ & $167(51.9)$ \\
\hline $\begin{array}{l}\text { Get post-exposure prophylaxis if } \\
\text { the source case is unknown or } \\
\text { positive }\end{array}$ & $157(48.8)$ \\
\hline $\begin{array}{l}\text { Document all information: type of } \\
\text { needle, department, how the injury } \\
\text { happened }\end{array}$ & $152(47.2)$ \\
\hline $\begin{array}{l}\text { Cover the wound after cleaning it } \\
\text { with a waterproof plaster or } \\
\text { dressing }\end{array}$ & $150(46.6)$ \\
\hline $\begin{array}{l}\text { Follow up at regular intervals }(6 \\
\text { weeks, } 3 \text { months, } 6 \text { months) }\end{array}$ & $144(44.7)$ \\
\hline $\begin{array}{l}\text { Encourage bleeding at the site of } \\
\text { puncture }\end{array}$ & $133(41.3)$ \\
\hline $\begin{array}{l}\text { Interpretation of Action } \\
\text { knowledge score }\end{array}$ & $227(70.5)$ \\
\hline $\begin{array}{l}\text { Poor knowledge } \\
\text { Sufficient knowledge }\end{array}$ & $95(29.5)$ \\
\hline
\end{tabular}

work where the majority of health care workers $(80.6 \%)$ of study participants reported that they practiced hand washing with soap and water after any direct contact with patients, while $12.9 \%$ reported that they seldom washed their hands while $6.5 \%$ never wash their hands after direct contact with the patients by glove. ${ }^{25}$ Generally our study participants' knowledge about items related to needle management were not good where some answered incorrectly on questions of possibility of changing needles for reuse of syringes $(25 \%)$, way of handling needles (70\%), possibility of bending needles (80\%). On the other hand, $57 \%$ knew the level at which the safety box should be emptied, $66 \%$ knew it should be out of reach of public, $65 \%$ knew that covering cuts is essential for preventing infection transmission. In other studies like Moss et al., 1994 it was observed that $20 \%$ of needles were recapped and $64 \%$ were disposed uncapped. ${ }^{26}$ In another study, $44.6 \%$ were of the opinion that needles should be recapped by single hand technique after use and among them 93\% practiced this technique. ${ }^{27}$ In another work, the vast majority of respondents, $86 \%$ agreed with the universal precautions guidelines that needles should never be recapped. On the other hand, 39\% usually and $7 \%$ always recap their used needles. ${ }^{28}$ In another study, $70 \%$ of respondents identified recapping as a risky practice and recognized that hand washing before and after every clinical practice is essential for prevention of cross-infection (100\%). ${ }^{29}$

Table (4): Attitude of health care workers towards hospital activities for occupational safety:

\begin{tabular}{|l|c|}
\hline \multicolumn{1}{|c|}{ Do you agree that? } & \multicolumn{1}{c|}{$\begin{array}{c}\text { Agree } \\
\text { n (\%) }\end{array}$} \\
\hline $\begin{array}{l}\text { Hospital efforts for infection } \\
\text { control are in continuous } \\
\text { improvement }\end{array}$ & $176(54.7)$ \\
\hline $\begin{array}{l}\text { Training for raising safety } \\
\text { awareness at the hospital is } \\
\text { adequate }\end{array}$ & $137(42.5)$ \\
\hline $\begin{array}{l}\text { Hospital supply of personal } \\
\text { protective equipment is adequate }\end{array}$ & $167(51.9)$ \\
\hline $\begin{array}{l}\text { There are enough announcements } \\
\text { on hospital policy and procedures } \\
\text { for occupational safety }\end{array}$ & $147(45.7)$ \\
\hline $\begin{array}{l}\text { The hospital does its best to } \\
\text { protect families of health care } \\
\text { workers as it protects its workers }\end{array}$ & $154(47.8)$ \\
\hline $\begin{array}{l}\text { Efforts of quality control teams are } \\
\text { good in follow up of } \\
\text { implementation of hospital rules } \\
\text { and regulations }\end{array}$ & $193(59.9)$ \\
\hline Attitude score: & $284(88.2)$ \\
\hline $\begin{array}{l}\text { Negative attitude } \\
\text { Positive attitude }\end{array}$ & $38(11.8)$ \\
\hline
\end{tabular}

The recapping of needles is strictly prohibited under the Occupational Safety and Health Administration (OSHA) blood borne pathogen standard. ${ }^{30}$

The current work revealed that about $30 \%$ had good knowledge on the actions to be

\section{The Egyptian Journal of Community Medicine}

Vol. 37

No. 1

January

2019 
Table (5): Factors affecting the knowledge of correct actions to be done in case of needle stick injuries:

\begin{tabular}{|c|c|c|c|c|}
\hline \multirow[b]{2}{*}{ Factors } & \multicolumn{2}{|c|}{ knowledge of post exposure actions } & \multirow[b]{2}{*}{$\begin{array}{c}\text { Chi } \\
\text { square }\end{array}$} & \multirow[b]{2}{*}{$P$ value } \\
\hline & $\begin{array}{c}\text { Inadequate } \\
\text { n }(\%)\end{array}$ & $\begin{array}{c}\text { Adequate } \\
\text { n (\%) }\end{array}$ & & \\
\hline $\begin{array}{l}\text { Job nature: } \\
\text { Physician } \\
\text { Nurse }\end{array}$ & $\begin{array}{r}65(67.4) \\
162(72.3)\end{array}$ & $\begin{array}{l}33(33.6) \\
62(27.7)\end{array}$ & 1.178 & 0.278 \\
\hline $\begin{array}{l}\text { Pre-employment training on work } \\
\text { safety and needle disposal: } \\
\text { Yes } \\
\text { No }\end{array}$ & $\begin{array}{r}58(47.2) \\
169(84.9)\end{array}$ & $\begin{array}{l}65(52.8) \\
30(15.1)\end{array}$ & 52.139 & 0.000 \\
\hline $\begin{array}{l}\text { History of needle stick injuries: } \\
\text { Yes } \\
\text { No }\end{array}$ & $\begin{array}{r}88(38.8) \\
139(61.2)\end{array}$ & $\begin{array}{l}47 \text { (49.5) } \\
48(50.5)\end{array}$ & 3.153 & 0.076 \\
\hline $\begin{array}{l}\text { Work duration: } \\
\leq 9 \text { years } \\
>9 \text { years }\end{array}$ & $\begin{array}{r}93(53.8) \\
134(89.9)\end{array}$ & $\begin{array}{l}80(46.2) \\
15(10.1)\end{array}$ & 50.37 & 0.000 \\
\hline $\begin{array}{l}\text { Department: } \\
\text { Non-surgical } \\
\text { Surgical }\end{array}$ & $\begin{array}{r}152(66.4) \\
75(80.6)\end{array}$ & $\begin{array}{l}77(33.6) \\
18(19.4)\end{array}$ & 6.47 & 0.01 \\
\hline
\end{tabular}

done in case of injury. On describing knowledge of the actions which should be done in case of needle stick injury, most of the participants knew they should use a sterile material to dry the wound, report the injury to the supervisor, get post-exposure prophylaxis if the source case is unknown and test oneself for HIV, HBV and HCV. In the study by Baghcheghi et al., 2011, the most common actions done after needle stick injuries by nursing staff were washing the area with soap and water and sending a blood sample to the laboratory while in $10 \%$ of cases, no specific action was done. ${ }^{31}$ In another study, most of the health care workers reported compression, washing the injured area with povidone iodide and soap were the most common actions in case of needle stick injuries, while in $0.09 \%$ of the cases nothing was done. ${ }^{32}$ Another study found that injured staff commonly applied pressure to the area, washed with soap, disinfected with alcohol, with Betadine and sent a blood sample to the lab, $1.8 \%$ made no action. ${ }^{33}$ Regarding follow up actions that have to be done after needle stick injury, the highest percentage did not know about follow up actions. This could be explained because of poor training courses attended by HCW. This is explained also by the significant association exists between attending training courses and having good knowledge score. In current study only $38.2 \%$ received pre-employment training on safe needle disposal. This low percentage of trained personnel may explain the high percentage with inadequate knowledge on infection control and that only $35 \%$ agreed that training offered by the hospital for raising safety awareness was enough. Participation in training is very much important in improving the knowledge of health care workers about methods of infection control and workplace safety. One study found that health care workers answered correctly and used appropriate hospital acquired infections control measures if they have received information from educational courses and scientific journals. $^{21}$

On describing the attitude of study population towards the activities done by the hospital for supporting occupational safety, it was found that $67 \%$ of them had a negative attitude towards these activities. This result was exactly as the findings of 
another study where $67.6 \%$ of health care workers believed that hospital authorities had done little to prevent hospital acquired infections. ${ }^{34}$

\section{Conclusion:}

High percentage of health care workers had inadequate knowledge about infection control practice in their hospital mostly due to lack of attending training courses and had negative attitude towards hospital activities for occupational safety.

\section{References}

1. Gabriel J. Reducing needle stick injuries among health care workers. Nurs Stand 2009; 23 (22): 41-4) (Norsayani MY, Noor Hassim I. Study on incidence of needle stick injury and factors associated with this problem among medical students. J Occup Health 2003; 45(3): 172-8.

2. Rele M, Mathur M, Turbadkar D. Risk of needle stick injuries in health care workers-a report. Indian J Med Microbiol 2002; 20(4): 206-7.

3. Mohammadi N, Hassanpour Dehkordi A, Nikbakhat Nasrabadi A. Iranian patients with chronic hepatitis struggle to do selfcare. Life Sci J. 2013; 10(1): 457-62.

4. World Health Organization (WHO). Hepatitis C fact sheet. 2012. Available at: www.who.int/mediacenter/factsheets/fs 164 /en/index.html. Accessed on 18/01/2013.

5. Ismail NA, Aboul Ftouh AM, ElShoubary WH, Mahaba H. Safe injection practice among health care workers in Gharbiya Governorate, Egypt. East Mediterr Health J. 2007; 13(4): 893-906.

6. Sharma R, Rasania S, Verma A, Singh S. Study of the prevalence and responses to needle stick injuries among health care workers in a tertiary care hospital in Delhi, India. Indian J. Community Med. 2010; 35 (1): 74-7.

7. Wicker S, Jung J, Allwinn R, Gottschalk R, Rabenau HF. Prevalence and prevention of needle stick injuries among health care workers in a German University hospital. Int Arch Occup Environ Health 2008; 81(3): 347-54.

8. Talaat M., Kandeel A., El-Shoubary W., Bodenschatz C., Khairy I., Oun S., Mahoney J. Occupational exposure to needle stick injuries and hepatits B vaccination coverage among health care workers in Egypt. Am J Infect Control 2003; 31(8): 469-74.

9. Leigh JP, Gillen M, Franks P, Sutherland S, Nguyen HH, Steenland K, et al. Costs of needlestick injuries and subsequent hepatits and HIV infections. Curr Med Res Opin. 2007; 23 (9): 2093105.

10. Schmid K, Schweger C, Drexler H. Needlestick injuries and other occupational exposures to body fluids amongst employees and medical students of a German University: incidence and follow up. J Hosp Infect 2007; 65(2): 124-30.

11. Lee J, Botteman M, Nicklasson L. A systematic review of the economic and humanisitic burden of needlestick injury in the United States. Am J Infect Control 2004; 32(3): E43.

12. Smith DR, Choe MA, Jeong JS, Yeon MY, Chae YR, An GJ. Epidemiology of needle stick and sharps injuries among professional Korean nurses. J Prof Nurs. 2006; 22(6): 359-66.

13. Centers for Disease Control. Hepatitis C information for health professionals, Atlanta 2011. Available at: http://www.cdc.gov/hepatitis/HCV/index.h tm (accessed 2013).

14. Yang L, Mullan B. Reducing needle stick injuries in health care occupations: an integrative review of the literature. ISRN Nurs 2011; 315432.

15. NIOSH. Alert: Preventing needle stick injuries in health care settings. (DHHS Public no. 2000-108), 1999.

16. Occupational Safety and Health Administration (OSHA) Factsheet. OSHA 's Blood borne Pathogens Standard, 2011. 
(http://www.osha.gov/Osh

Doc/data_BloodborneFacts/bbfact01.pdf. 17. Reda1 AA, F Shiferaw, Mengistie B and Vandeweerd JM. Standard Precautions: Occupational Exposure and Behavior of Health Care Workers in Ethiopia. PLoS ONE 2010, 5 (12): 1442017. 18. Rampal L, Zakaria R, Sook UL, Zain A. Needle stick and sharps injuries and factors associated among health care workers in a Malaysian hospital. Eur J Soc Sci 2010; 13: 354-62.

19. Peng BI, Tully PJ, Boss K and Hiller JE. Sharp injury and body fluid exposure among health care workers in an Australian tertiary hospital. Asia Pac J Public Health 2008; 20(2): 139-47.

20. Zafar A, Aslam N, Nasir N, Meraj R and Mehray V. Knowledge, attitude and practices of health care workers regarding needle stick injuries at a tertiary hospital in Pakistan. J Pak Med Assoc. 2008; 58(2): 57-60.

21. Cristiana Parmeggiani, Rossella Abbate, Paolo Marinelli and Italo F. Angelillo. Healthcare workers and healthcare associated infections: knowledge, attitudes and behavior in emergency departments in Italy. BMC Infectious diseases 2010; 10:35.

22. Centers for Disease Control and Prevention. Guidelines for infection control in health care personnel. Infect. Control Hosp. Epidemiol. 1998; 19: 445.

23. International Labor Office. An ILO code of practice on HIV/AIDS and the world of work. Geneva, Switzerland: ILO, 2001.

24. Motamed N, Mahmoodi FB, Khalilian A, Peykanheir $M$ and Nozari $M$. Knowledge and practices of health care workers and medical students towards universal precautions in hospitals in Mazandaran Province. Eastern Mediterranean Health Journal 2006; 12(5). 25. A.Bhardwaj, N. Sivapathasundaram, MF Yusuf, AH Minghat, KMM Swe, NK
Sinha. The prevalence of accidental needle stick injuries and their reporting among health care workers in orthopedic wards in general hospital Melaka, Malaysia. Malays Orthop J 2014; 8(2):6-13.

26. Moss ST, Clark RF, Guss DA, Rosen $P$. The management of sharps in the emergency department: is it safe? J Emerg Med 1994; 12(6): 745-52.

27. Jayadevan Sreedharan, Jayakumary Muttappallymyalil, Manda Venkatramana. Knowledge and practice of standard measures in occupational exposure to blood and body fluids among nurses in a university hospital in the United Arab Emirates. Italian Journal of Public Health 2010; 7(1): 90-94.

28. Clarence David McGaw, Ingrid Tennant, Hyacinth E Harding, Shamir O Cawich, Ivor W Crandon, CA Walters. Health care workers attitudes to and compliance with infection control guidelines in the operating department at the university hospital of the West Indies, Jamiaca. International Journal of Infection Control 2012; 8:1-9.

29. Olufemi Oludare Aluko, Ayobami Emmanuel Adebayo, Titilayo Florence Adebisi, Mathew Kolawole Ewegbemi, Abiodun Tolani Abidoye and Bukola Faith Popoola. Knowledge, attitudes and perceptions of occupational hazards and safety practices in Nigerian healthcare workers. BMC Research Notes 2016; 9:71. 30. Occupational exposure to blood borne pathogens-OSHA. Final rule. Fed Regist $1991 ; 6 ; 56: 4004-4182$.

31. Baghcheghi N, Koohestani HR, Rezaeik, Seraji A, Abedi AR. Prevalence of needle stick /sharps injuries among nursing students and related factors. Iran Occup Health J. 200; 7(4): 32-9.

32. Rakhshani F, Heydari MT, Barati Bani S. Prevalence of needle stick injury among the health care professionals in Zahedean medical sciences university. Iran J. Epidem 2008; 4(3-4): 87-91. 
33. FDA. Sharps Disposal Containers. 2013.

34. Irene Ocran and Daniel Nii Ayree Tagoe. Knowledge and attitude of health care workers and patients on healthcare associated infections in a regional hospital in Ghana. Asian Pac J Trop Dis 2014; 4(2): 135-139. 